\title{
CAPITAL ADEQUACY IN THE ROMANIAN BANKING SYSTEM
}

\author{
Associate Professor PhD Socol Adela, „1 Decembrie 1918” University of Alba Iulia, \\ adelasocol@yahoo.com
}

\begin{abstract}
The purpose of this paper is to studying the existing national and international criteria and methodologies related to the banking capitals measurement. We examine the minimum requirements for banking capital and the actual status of Romanian banks in terms of solvency ratio. The paper analyzes the risk-based capital ratios through a case study at the level of a banking society from Romania. We quantify the capital charges by reference to the regulatory capital expressed as a percentage of total risk-weighted assets and by reference to the Tier 1 capital expressed as a percentage of risk-weighted assets. Our research reveals that the level of capitalization is relevant for the ability of banks to absorb the losses generated by either exogenous shocks induced by the domestic and international macroeconomic environment, or by the inappropriate management of the endogenous risks associated with banking activity.
\end{abstract}

Key Words: Solvency Indicators, Adequate Banking Capitalization, Regulatory Capital

JEL Classification: G21, G24

\section{Theoretical background.}

The present stage of knowledge in the area related to the subject shows that capital adequacy is a process of dimensioning of the banking societies capital imposed by legislative requirements. Capital adequacy implies the conventional assessment of the minimal level of capital, according to certain parameters, which reflect the dimension of banking activity and of related risks, capable to provide a correlation between the supposed obtained benefits and potential loss caused by a certain risk level. In order to stop the tendencies of credit societies to maximize their profits by using intensively their own funds, banking supervising authorities impose the maintaining of a certain balance between the funds owned by these societies and the level of the borrowed capital, establishing restrictions concerning the excessive using of their own resources. In a banking society, the main role of the capital, besides the transfer of the property, is to act like a pad in order to amortize the unexpected loss, to protect the deponents and to assure the confidence of the investors and rating agents.

Specialized literature treats the capital adequacy issue using the following defining concepts: regulatory capital and economic capital. Regulatory capital refers to minimal capital requirements which banks must own according to the regulations made by national supervision authorities. The establishment of capital requirements has the main objective to assure the stability and the viability of national banking system. Economic capital has to act like a pad of protection against all the risks that may put in danger the solvency of the bank. Economic capital is a recent notion used in the financial theory and financial practice which is defined as being the level of capital required for the amortization of normal loss (beyond those expected) generated by the clients' inobservance of paying their obligations which had been established by the means of a previous contract. More elevated the level of the capital of a bank is, smaller will be the probability that the bank enters in total payment impossibility, or to suffer a judicial reorganization or bankrupt. In consequence, the foundation on real bases of the volume of banking capitalization has an important role because the financial health of that certain institution depends on it. 
The general approach of capital adequacy process shows that its incipient stages are directly linked to the activity of Basel Committee- Basel Committee on Banking Supervision. In 1988 , in the context of international banking field development, the Committee had decided to introduce a system of capital measurement known as the Basel Agreement I [International Convergence of Capital Measurement and Capital Standards, Basel, 1988]. The agreement imposed a minimal standard of capital for banks, according to which the basic capital of a bank must be maintained at an $8 \%$ level from banks exposure. The regulation was establishing a minimal report of $8 \%$, calculated as a ratio between the funds owned and level-headed actives depending on risks. To different actives categories it was reserved certain risk level between 0 and $100 \%$. Since 1988 , this structure was progressively introduced in the member states of European Union and in many other countries, which had recognized the importance of banking capital regulation.

In Romania, starting from 1990, there was established regulations regarding the banking solvency [National Romanian Bank's Regulation no.4, regarding banking solvency, 1994]. Since 2003, the national legislation related with the field of banking solvency was improved and Romanian active banking societies, in their quality of credit institutions, permanently had to maintain the solvency indicatory up to a level of $12 \%$ [National Romanian Bank's Regulation no. 12, regarding the supervision of the solvency and of the exposure of large credit institutions, 2003]. The solvency indicatory shows the funds owned, considered to be a part of the entire amount of actives, and also a part made of elements exterior to balance sheet, payments to agents, modified and adjusted according to risks. The minimal limit of solvency indicatory established in our country was higher than that of $8 \%$ imposed by Basel Agreement I, thus showing a more cautious attitude of regulation authority related to the field- National Bank of Romania.

In June 1999, the Basel Committee proposed a revision of the capital adequacy structure, imposed by the development of risk administration methods and by the fixity of the condition of Basel Agreement I. After intensive interactions with banks, industrial groups and national supervision authorities, in November 2005, was finalized and signed Basel Capital Agreement II [International Convergence of Capital Measurement and Capital Standards: a Revised Framework Comprehensive Version, Basel, 2006]. Basel Agreement II is made up of three pillars that support one another: Pillar 1 regulates the minimum capital requirements necessary for covering specific risks of banking: credit risk, market risk and operational risk; Pillar 2 is represented by the process of prudential supervision, which imposes the national supervision authorities to make sure that banks dispose of healthy internal procedure to evaluate their own risks; Pillar 3 intends to consolidate market discipline by increasing the financial transparency of banks.

In Romania, in the context of preliminary preparations of Romanian banking system for applying the conditions of Basel II Agreement, at the end of 2006, it was adopted a set of normative acts in the field of banking capital adequacy. In this way, the concept of capital adequacy is also present in our country, but in the first years of development of the new Romanian banking system, the specific legislation was making references only to capital requirements (art. 40-43 from banking Law no. 58/1998) and lately in the context of the implementation of Basel Agreement II, the concept of capital adequacy was also used by national regulations. The main settlements regarding the banking capital adequacy are the following:

- Government Emergency Ordinance No. 99/2006 on credit institutions and capital adequacy, as subsequently amended and supplemented by Law No. 227/2007 settles the general frame of risk management in banks.

- Regulation No. 18/23/2006 issued by National Bank of Romania and National Securities Commission on own funds of credit institutions and investment firms requires credit institutions, Romanian legal entities, branches of third-country credit institutions operating in Romania, financial investment services undertakings, credit co-operatives within credit co-operative networks and investment management companies to maintain a level of own funds at least equal to the amount of capital requirements for credit risk, dilution risk, position risk, settlement risk, 
counterparty credit risk, currency risk, commodities risk and operational risk.

- National Bank of Romania Order No. 12/2007 on the reporting of minimum capital requirements for credit institutions transposes into the Romanian legislation the COREP (Common solvency ratio reporting framework) reporting forms drawn up by the Committee of European Banking Supervisors (CEBS), which stands for the instrument of banking supervision according to Basel II principles. The new norms require the observance, both on an individual and on a consolidated basis, of requirements for own fund structure and the capital requirements for credit risk, market risk, operational risk, dilution risk, position risk, settlement risk, counterparty credit risk, commodities risk.

Banking capital adequacy issue related to risks, raised not only the interest of international banking field (directly interested in the stability and the proficiency of banking field), but also the interest of scientific communities. Generally, this interest has been materialized even in the period preceding the suggestion of modification of Basel Agreement I, in 1999. Thus, even in 1980's, some theoretical approaches presented the methods in which the capital requirements must be taken into consideration by the shareholders and by the managers of banking societies in what concerns risk management [M. Koehn and A. Santomero, 1980], [J. Rochet, 1992], [A.V. Thakor, 1996]. Banking risk management aspects are the object of the study made by A. Powell, with applications referring to countries which are implied in a development process [A. Powell, 1989]. Following this study, the author, collectively [V. Balzarotti , M. Falkenheim, 2002], made it more complete, taking into consideration the risk issue and the capital adequacy related to banking field, taking as case study Argentina and its financial crisis.

The period of the 90's may be considered the incipient period of empirical studies in the field of banking capital adequacy, in different countries. Others authors [K.T. Jacques and P. Nigro, 1997] examined the impact of capital requirements upon solvency indicatory, based on regressive patterns, using information taken from the American banking system and for Switzerland [B. Rime, 1998].

After 2000, it must be taken into consideration the emergence in specialized literature and in banking field of some complex studies which analyze the new Basel Agreement II and the consequences of its application in the case of different national states. An important paper, without denying the importance of the Basel Agreement I for the prudential supervision of banking systems and for banking capitalization, put the accent on the wide spreading of Basel I in a banking field more and more complex [J. Danielsson, P. Enbrechts, Ch. Goodhart, C. Keating, F. Muennich, O. Renault, H.S. Shin, 2001]. The authors show that the solvency indicatory provided by Basel cannot be scientifically determined and we need to take into considerations the complexity of the administration approaches of banking risks and the ways in which we cam measure the capital of a banking society.

In short time after the emergency of the consultative form of the new Basel Agreement II, Hellman T.F, Murdock K.C and Stiglitz J.E (in 2000) study the interdependence of moral hazard and prudential regulations in banks, asking if it is sufficient the capital of the banks to cope with credit risks, market and operational risks. The solutions revolve round the necessity of the implementation of banking prudential regulations in capital matter, but with the mention that these regulations must be flexible enough to allow the bank to establish their own risk profiles in immediate relation with minimal capital [Hellman T.F, Murdock K.C and Stiglitz J.E, 2000)]. After its signing in 2005, Basel Agreement II has become a subject matter for those interested in banking prudential regulations issue related to capital and risks. M.K. Ong describes the three pillars of the new agreement and approaches the methodology of advanced measurements in the administration of operational risk. In the same time, he presents a form of the data base of operational loss and of insurance of operational risks [M.K. Ong, 2005].

Specialized studies of the last few years promote more and more elaborated econometrical patterns of banking risk administration and banking capital adequacy. Thus, S. Peura and E. 
Jokivuolle study the banking capital requirements, a study based on stress tests simulations [S. Peura and E. Jokivuolle, 2004]. Others authors study the allocation of capital at the level of banking societies, a study based on RAROC methodologies (Risk Adjusted Return on Capital) and EVA (Economic Value Added) methodology [N. Stoughton and J. Zechner, 2007]. F. Heid analyses the cyclic effects of the new agreement of capital and capital volatility [F. Heid, 2007]. C. Homburg and P. Schepereel study the allocation of capital based on VAR methodology, analyses and make a comparison between some well-known patterns of capital allocation, both theoretical, but also practical (cost gap, beta method) [C. Homburg and P. Schepereel, 2008]. T. Eyssel and I. Arshadi study capital requirements which are imposed to bank societies taking the form of risk capital [T. Eyssel and I. Arshadi, 2008].

In Romania, the capital requirements of banking societies related to risks and all their aspects, in the context of Basel Agreement II, were approached starting from 2000 by the banking community and by the officials of National Bank of Romania, preoccupied with the stage of preparing the Romanian banking system for the implementation of the new agreement. Also, specialized studies were elaborated in this domain by officials of academic field. In the beginning, in the period 2000-2005, these studies generally had an informative character related to the provisions of Basel Agreement II, because of the insufficient knowledge related to the theme in the national economic field and the wide spreading of the new agreement. Informative references to the role of the new agreement in the achievement of a high security level and solidity of the Romanian banking system belong to some authors [N. Danila, L. Anghel, M.I. Danila, 2002]. Various opinions lead to the idea that Romanian banking system was not ready yet for the implementation of the new agreement. P. Tulin observed the necessity of preparing of Romanian banking societies for the successfully implementation of Basel Agreement II [P. Tulin, 2004]. S. Lazarescu presented in a general way the new agreement and he insisted on its relations with European Capital Requirements Directives [S. Lazarescu, 2005].

Subsequently, in the period 2005-2008, in the field related to the theme we treated, in the national specialized literature there were conceived complex studies related to the banking risk administration field and capital adequacy. It is about certain measurement methodologies of banking risk, based on complex econometrical instruments in conformity with Basel Agreement II. M. Opritescu individually and collectively, studies in an ample treatise of banking risks management, the banking risks, in conformity with Basel Agreement II [M. Opritescu, 2006]. I. Trenca presents the methods of measuring the credit risk and the necessity of the development of an efficient management, with emphasis on the determination of the capital due to a projected credit portofolio [I. Trenca, 2006]. N. Dardac and B. Moinescu conceived a quantitative evaluation of credit risk, analyzing the estimation methodologies of unreimbursement probability. Credit risk issue is subsequently resumed by the same two authors, in a study concerned with the validation techniques of the internal patterns of credit risk [N. Dardac and B. Moinescu, 2006]. Similar to foreign studies, the last few years are marked by the emergence in our country of some publications which do not limit their selves just to take over and to comment upon Basel Agreement II. It is the case of some studies specialized on certain branches of banking risk administration. This fact indicates the strong involvement of academic communities and of officials belonging to banking fields in achieving advanced information related to the field of banking risk administration and capital adequacy.

\section{Description of the financial framework of capital adequacy in banking societies.}

The purpose of the capital adequacy framework Basel II Agreement is to ensure that a bank's capital position is consistent with its overall risk profile and strategy and, as such, will encourage early supervisory intervention. Supervisors should have the ability to require banks to 
hold capital in excess of minimum regulatory capital ratios - a point underscored in the course of the Committee's discussions with supervisors from non-G-10 countries. Furthermore, the new framework stresses the importance of bank management developing an internal capital assessment process and setting targets for capital that are commensurate with the bank's particular risk profile and control environment.

The national regulations in the field of banking capital adequacy, according to the Basel II Agreement, establish the two kind of capital:

1. Tier I (Core Capital or Basic Equity) considered the key element of capital on which the main emphasis should be placed is equity capital and disclosed reserves. This key element of capital:

- is the only element common to all countries' banking systems;

- it is wholly visible in the published accounts and is the basis on which most market judgments of capital adequacy are made;

- it has a crucial bearing on profit margins and a bank's ability to compete.

This emphasis on equity capital and disclosed reserves reflects the importance the national supervisor authorities attaches to securing an appropriate quality, and the level, of the total capital resources maintained by banks.

Tier 1 comprises the highest quality capital elements which fully satisfy all of the following essential characteristics:

- provide a permanent and unrestricted commitment of funds;

- be freely available to absorb losses;

- not impose any unavoidable servicing charge against earnings; and

- rank behind the claims of depositors and other creditors in the event of winding-up.

In Romanian banking system (pursuant to Regulation No. 18/23/2006 issued by National Bank of Romania and National Securities Commission on own funds of credit institutions and investment firms), Tier 1 capital consists of:

a) subscribed and paid-up share capital, except cumulative preferential shares or, as appropriate, the core capital made available to the branch in Romania by the third-country credit institution;

b) share premiums, received entirely, related to the equity capital;

c) legal reserves, statutory reserves and other reserves, as well as the retained earnings, following profit distribution;

d) net profit of the latest financial year, before its distribution in accordance with the decisions made at the General Meeting of Shareholders, to the limit of the amount intended to be earmarked for each of the destinations (stipulated under let. a) -c)).

2. Tier 2 (Supplementary capital) includes other elements which, to varying degrees, fall short of the quality of Tier 1 capital, but nonetheless contribute to the overall strength of an entity as a going concern, and is divided into: Upper Tier 2 capital - comprising elements that are essentially permanent in nature, including some forms of hybrid capital instruments which have the characteristics of both equity and debt; and Lower Tier 2 capital - comprising instruments which are not permanent (i.e. dated or limited life instruments).

In Romanian banking system (pursuant to Regulation No. 18/23/2006 issued by National Bank of Romania and National Securities Commission on own funds of credit institutions and investment firms), Tier 2 capital comprises:

a) base Tier 2 capital;

b) additional Tier 2 capital.

Base Tier 2 capital consists of reserves from tangible asset revaluation, adjusted for the related fiscal obligations, which are foreseeable upon calculating own funds and other items and perpetual securities and other similar instruments that fulfill cumulatively the specific conditions. To these may add the cumulative preferential shares (other than those representing items of the 
additional Tier 2 capital). The additional Tier 2 capital includes temporary cumulative preferential shares and the capital in the form of subordinated loans.

We present a case study of implementing current capital requirements at the level of a Romanian banking society. National Bank of Romania sets and monitors capital requirements for the banking society as a whole and requires the bank to maintain a prescribed ratio of total capital to total risk-weighted assets. We analyze the bank's regulatory capital into two tiers:

- Tier 1 capital, which includes ordinary share capital, share premium, translation reserve and minority interests after deductions for goodwill and intangible assets and $50 \%$ of the interest in financial and insurance companies

- Tier 2 capital, which includes qualifying subordinated liabilities, fixed assets revaluation reserves after deduction of $50 \%$ of the interest in financial and insurance companies

The national legislation sets two capital ratio: a risk-based capital ratio (solvency ratio that will be $>8 \%$ ) and ratio of Tier 1 capital to risk weighted assets

Under the risk-based capital adequacy framework, a Tier 1 and Tier 2 capital adequacy are measured by means of a risk-based capital ratio calculated by dividing its capital base by its total risk-weighted assets:

$$
\text { Solvency } \cdot \text { ratio }=\text { Risk }- \text { based Capital Ratio }=\text { Capital base } / \text { Total Risk }- \text { Weighted Assets }
$$

Ratio of Tier 1 capital to risk weighted assets shows Tier 1 capital as a share of total riskweighted balance sheet assets and off-balance sheet items, net of provisions.

Table no. 1

A bank's regulatory capital position in accordance with the statutory regulations issued by the National Bank of Romania at 31 December year $N$

RON

\begin{tabular}{|c|c|c|}
\hline Indicator & 31 December $N$ & 31 December $N-1$ \\
\hline \multicolumn{3}{|l|}{ TIER 1 CAPITAL } \\
\hline Share capital & 611080 & 393355 \\
\hline Share premium & 98601 & 94199 \\
\hline Translation reserves & 447902 & 216601 \\
\hline Less intangible assets & $(7397)$ & $(9056)$ \\
\hline Less $50 \%$ of the interest in financial companies & $(73483)$ & (35868) \\
\hline TOTAL & 1076703 & 659231 \\
\hline \multicolumn{3}{|l|}{ TIER 2 CAPITAL } \\
\hline Revaluation reserves & 26896 & 9855 \\
\hline Subordinated liabilities & 243485 & 236764 \\
\hline Less $50 \%$ of the interest in financial companies & $(73483)$ & $(35868)$ \\
\hline TOTAL & 196898 & 210751 \\
\hline Total regulatory capital & 1273601 & 869982 \\
\hline Risk weighted assets & 10459289 & 5958940 \\
\hline \multicolumn{3}{|l|}{ CAPITAL RATIOS } \\
\hline $\begin{array}{l}\text { Solvency ratio (total regulatory capital expressed as a } \\
\text { percentage of total risk-weighted assets) }\end{array}$ & $12,18 \%$ & $14,60 \%$ \\
\hline $\begin{array}{l}\text { Ratio of Tier } 1 \text { capital to risk weighted assets (total Tier } 1 \\
\text { capital expressed as a percentage of risk-weighted assets) }\end{array}$ & $10,29 \%$ & $11,06 \%$ \\
\hline
\end{tabular}


Findings. The example has revealed that the bank recorded the lower solvency ratio $(12,8$ percent at end- $\mathrm{N}$, down 2,42 percentage points from end- N-1). The main factor behind this development is the ongoing expansion of non-government credit, given that bank's own funds posted a slower growth pace. Nevertheless, the solvency ratio has been maintained at an adequate level, exceeding the minimum level laid down in prudential regulations applicable in Romania $(8 \%)$.

At the level of Romanian banking system, according to Financial Stability Report, published in 2008 by National Bank of Romania, banks' solvency indicators continued to decline in 2007, against the background of non-government credit expansion, household loans in particular. The Romanian banking system remains adequately capitalized, but in 2007, the downtrend followed in the past years by the overall solvency ratio of credit institutions was sharper, this indicator dropping 5.4 percentage points as compared to the end-2006, to 12.7 percent. For the first time in the past eight years, three banks reported solvency ratios in a range between 8 percent and 10 percent, whilst other three banks recorded solvency ratios ranging from 10 percent to 12 percent. The largest concentration is seen in the range of 12 percent and 16 percent, as twelve banks reported solvency ratios within this range. At end-2007, only five banks posted solvency ratios higher than 30 percent, as compared with eight banks at end-2006.

We consider that there is a major risk for banks (especially for the banks whose solvency ratio is close to the 8 percent minimum level) to have solvency problems. This risk is associated with the difficulty to currently assess (at the end of 2008) the impact exerted by the entry into force of the new prudential regulations on capital adequacy, which set forth the enforcement of Basel II principles since 1 January 2008.

We believe that the Romanian banking system remains well capitalized, and the solvency ratio will raise no problems in the short run, considering the maintenance of a safe margin of the aggregate level of this indicator in relation to the minimum level laid down by regulations. But the banks' market share will depend on the increase in own funds (via new equity capital contributions from shareholders, subordinate loans, higher reserves, etc). We conclude that an adequate level of capitalization indicators of credit institutions secures the maintenance of the overall financial system stability, considering that these institutions are the key component of the Romanian financial market.

\section{References:}

1. Danielsson J., Enbrechts P., Goodhart Ch., Keating C., Muennich F., Renault O., Shin H.S., (2001), An Academic Response to Basel II, Special paper no. 130, LSE Financial Markets Group and ESRC Research Centre, may, ISSN 1359-9151-130

2. Dănilă N., Anghel L., Dănilă M.I., (2002), Managementul lichidităţii bancare, Editura Economică, Bucureşti

3. Dardac N., Moinescu B., (2006), Evaluarea cantitativă a riscului de credit din perspectiva Basel II, Revista Economie teoretică şi aplicată, nr. 5(500)

4. Dardac N., Moinescu B., (2006), Tehnici de validare a modelelor interne pentru riscul de credit, Revista Economie teoretică şi aplicată, nr. 9(504)

5. Eyssell T., Arshadi I. (2008), The wealth effects of the risk-based capital requirement in banking. The evidence from the capital market, Journal of Banking and Finance, p. 179-197

6. Heid F., (2007), The cyclical effects of the Basel II capital requirements, Journal of Banking \& Finance, Volume 31, Issue 12, p. 3885-3900

7. Hellman T.F., Murdock K.C., Stiglitz J.E., (2000), Liberalization, Moral Hazard in Banking and Prudential Regulation: Are Capital Requirements Enough?, American Economic Review, American Economic Association, vol. 90 (1), pp. 147-165 
8. Homburg C., Scherpereel P. (2008), How should the cost of joint risk capital be allocated for performance measurement?, European Journal of Operational Research, 187 (1), p. 208-227

9. Jacques K.T., Nigro P., (1997), Risk-Based Capital, Portfolio Risk and Bank Capital: A Simultaneous Equations Approach, Journal of Economics and Business, 49, pp. 533547

10. Koehn M., Santomero A., (1980), Regulation of Bank Capital and Portfolio Risk, Journal of Finance 35, no. 5 (December): 1235-44

11. Lazarescu S., (2005), Noul Acord de la Basel - prezentare de ansamblu, Revista Tribuna Economică, nr. 21

12. Ong M.K., (2005), The Basel Handbook: A guide for Financial Practitioners, Incisive Media Ltd. With KPMG, London, UK

13. Opritescu M., Spulbar C., Nanu R., Opritescu A., Berceanu O. (2006), Tratat de management a riscurilor bancare, Editura Universitaria, Craiova

14. Peura S., Jokivuolle E., (2004), Simulation based stress tests of banks' regulatory capital adequacy, Journal of Banking \& Finance, Volume 28, Issue 8, p. 1801-1824

15. Powell A., (1989), The Management of Risk in Developing Country Finance, Oxford Review of Economic Policy, 5 (4), pp. 69-87

16. Powell A., Balzarotti V., Falkenheim M., (2002), On the use of portfolio risk models and capital requirements in emerging markets: the case of Argentina, World Bank Economic Review, vol. 16, 2, pp. 197-212

17. Rime B., (1998), Capital Requirements and Bank Behaviour: Empirical Evidence for Switzerland, Swiss National Bank

18. Rochet J. C., (1992), Capital Requirements and the Behaviour of Commercial Banks, European Economic Review 36, no. 5 (June): 1137-70

19. Stoughton N.M., Zechner J., (2007), Optimal capital allocation using RAROC and EVA, Journal of Financial Intermediation, Volume 16, Issue 3, p. 312-342

20. Trenca I., (2006), Noi cerinte privind managementul riscului de creditare, Revista Economie teoretică şi aplicată, nr. 3(498)

21. Tulin P., (2004), Sistemul bancar romanesc nu e pregatit pentru Basel II, Revista e-finance, nr. 43

22. Basel Committee on Banking Supervision (2006) Basel II: International Convergence of Capital Measurement and Capital Standards: A Revised Framework, June 2006, BIS, Basel, Switzerland, http:// www.bis.org/publ/bcbs128.htm

23. National Bank of Romania (2007) Report on Financial Stability for the Year 2007, May 2007, http://www.bnr.ro/publicații/Raport_asupra_stabilității_financiare 